\title{
Atrial natriuretic peptide in stable and decompensated chronic obstructive pulmonary disease
}

K Skwarski, M Lee, L Turnbull, W MacNee

\begin{abstract}
Background-Plasma levels of atrial natriuretic peptide (ANP) are elevated in patients with chronic obstructive pulmonary disease (COPD) and may have a role in preventing oedema formation in these patients.
\end{abstract}

Methods-Plasma ANP levels were measured in 60 patients with COPD and these measurements were related to pulmonary haemodynamics, response to treatment during exacerbations, and clinical patterns of the stable disease.

Results-Plasma ANP levels did not correlate significantly with right atrial or pulmonary arterial pressures but did correlate significantly with both the right ventricular end diastolic volume and right ventricular wall volume measured by magnetic resonance imaging. Oxygen ( $21 / \mathrm{min}$ by nasal prongs for 30 minutes) did not change the mean pulmonary arterial pressure or the level of plasma ANP. In 20 patients with an acute exacerbation of COPD plasma ANP levels were higher in those with oedema (302 (185) $\mathrm{pg} / \mathrm{ml}$ ) than in those without oedema (87 (43) $\mathrm{pg} / \mathrm{ml}$ ). Oxygen given for one hour had no effect on plasma levels of ANP. However, plasma ANP levels fell over the first three days during treatment in those with oedema, the fall correlating with the change in body weight. In a further 20 stable patients with hypoxic COPD, those with hypercapnia and previous episodes of oedema had higher levels of plasma ANP (120 (50) $\mathrm{pg} / \mathrm{ml}$ ) than normocapnic patients with no previous oedema (54 (15) $\mathrm{pg} / \mathrm{ml}$ ).

Conclusions-The level of ANP is high in the plasma of patients with COPD, particularly during exacerbations in those with oedema. The association of a high plasma ANP level and volume overload is shown by the fall in ANP levels with treatment of the oedema, and the correlation between levels of ANP and right ventricular end diastolic or wall volumes.

(Thorax 1993;48:730-735)

The traditional view of the development of peripheral oedema in patients with chronic obstructive pulmonary disease (COPD) sug- gests that chronic hypoxia is responsible for pulmonary vasoconstriction which eventually $\vec{\circ}$ leads to irreversible pulmonary hypertension, increased right ventricular work, and right ventricular failure. ${ }^{12}$ This sequence of events has been challenged recently. ${ }^{3}$ The right ventricular performance is relatively well preserved in patients with COPD, even in the face of pulmonary hypertension. ${ }^{45}$ Moreover, the decline in right ventricular function in patients with COPD presenting with oedema may not be as a direct result of an augmented right ventricular afterload.56 Furthermore, not all patients with COPD and pulmonary hypertension develop oedema, suggesting decompensated cor pulmonale during exacerbations of their condition. Several authors have suggested that abnormalities in salt and water balance underlie the clinical syndrome of oedema in patients with hypoxic COPD. ${ }^{7-10}$

Since de Bold et $a l^{11}$ showed that human cardiocytes in both atria produce and store a potent natriuretic peptide-atrial natriuretic peptide (ANP) - this substance has been extensively studied in patients with congestive cardiac failure. In these patients plasma ANP levels correlate variably with the pulmonary arterial or right atrial pressures. ${ }^{12-15}$ The general view, however, is that atrial stretch is the major stimulus to the release of ANP.12 1617

The role of ANP in the development of the clinical syndrome of cor pulmonale is unknown. Recent reports of measurement of ANP levels in patients with various chronic lung diseases including COPD have shown $N$ that these patients have higher levels of $\mathbb{\omega}^{\circ}$ plasma ANP than normal subjects. ${ }^{17-19}$ O Preliminary studies also suggest that levels of 0 ANP are even higher in those with decompensated cor pulmonale. Plasma ANP levels correlate weakly with pulmonary arterial pressure and right atrial pressures in some studies $^{17-20}$ but not in others, ${ }^{21}$ and are not influenced by short term supplemental oxygen. ${ }^{21}$

The aim of this study was to extend these observations on ANP to a larger group of patients with COPD. In particular we wished to correlate plasma ANP levels, not only with pulmonary haemodynamics, but also with right ventricular dimensions, the effects of treatment during acute exacerbations of COPD, and with the clinical patterns of the stable disease. 


\section{Methods}

STUDY POPULATION

Sixty patients with COPD were studied and formed three separate groups. Twenty patients were studied when clinically stable (table 1) at least 6 weeks after their last exacerbation of COPD. In these patients measurements of pulmonary haemodynamics were made as part of their assessment for domiciliary oxygen therapy. A further 20 patients were studied on admission to hospital with an acute exacerbation of COPD (table 1). The remaining 20 patients with COPD presented at the outpatient clinic when clinically stable and were divided into two clinical patterns: so called "blue bloaters" $\left(\mathrm{PaO}_{2}<8.0 \mathrm{kPa}, \mathrm{PaCO}_{2}>6.0 \mathrm{kPa}\right.$, past history of peripheral oedema) and "pink puffers" $\left(\mathrm{PaO}_{2} \geqslant 8.0 \mathrm{kPa}, \mathrm{PaCO}_{2} \leqslant 6.0 \mathrm{kPa}\right.$, no past history of peripheral oedema) (table 2) on the basis of their blood gas values and clinical findings.

\section{HAEMODYNAMIC STUDY}

Each patient was studied semisupine, resting at an angle of $45^{\circ}$. An arterial line was inserted into the non-dominant brachial or radial artery under local anaesthetic ( $2 \%$ lignocaine) to sample arterial blood. A Swan-Ganz thermodilution pulmonary arterial catheter (Edwards Laboratories, Santa Anna, California) was passed from a right antecubital vein to the pulmonary artery under local anaesthetic and coupled to a pressure transducer attached to a haemodynamic cart (Hewlett Packard Model No 78339A).

Table 1 Mean (SD) characteristics of patients with COPD studied when stable or during an acute exacerbation.

\begin{tabular}{lll}
\hline & Stable & Acute \\
\hline n & 20 & 20 \\
Age (years) & $67(6)$ & $70(7)$ \\
FEV $_{1}(1)$ & $0 \cdot 7(0 \cdot 2)$ & $0 \cdot 6(0 \cdot 2)$ \\
$\mathrm{FVC}(1)$ & $1 \cdot 70 \cdot 4)$ & $1 \cdot 1(0 \cdot 5)$ \\
$\mathrm{PaO}_{2}(\mathrm{kPa})$ & $6 \cdot 8(0 \cdot 8)$ & $6 \cdot 7(0 \cdot 9)$ \\
$\mathrm{PaCO}_{2}(\mathrm{kPa})$ & $6 \cdot 5(0 \cdot 9)$ & $6 \cdot 7(1 \cdot 7)$ \\
$\mathrm{H}^{+}(\mathrm{nmol} / \mathrm{l})$ & $41(0 \cdot 9)$ & $44(1 \cdot 8)$ \\
\hline
\end{tabular}

$\mathrm{FEV}_{1}$ - forced expiratory volume in one second; FVCforced vital capacity; $\mathrm{PaO}_{2}, \mathrm{PaCO}_{2}$ - partial pressures of oxygen and carbon dioxide; $\mathrm{H}^{+}-$hydrogen ion concentration.

Table 2 Mean (SD) characteristics of patients with stable COPD studied at presentation at the outpatient clinic.

\begin{tabular}{lccl}
\hline & $\begin{array}{l}\text { "Blue } \\
\text { bloaters" }\end{array}$ & $\begin{array}{l}\text { "Pink } \\
\text { puffers" }\end{array}$ & $p$ \\
\hline n & 11 & 9 & \\
Age (years) & $60(8)$ & $70 \cdot 5(5)$ & NS \\
$\mathrm{FEV}_{1}(1)$ & $0 \cdot 6(0 \cdot 3)$ & $0 \cdot 9(0 \cdot 2)$ & $<0 \cdot 02$ \\
$\mathrm{FVC}_{(1)}$ & $1 \cdot 9(0 \cdot 6)$ & $2 \cdot 2(0 \cdot 8)$ & $\mathrm{NS}$ \\
$\mathrm{PaO}_{2}(\mathrm{kPa})$ & $6 \cdot 9(1 \cdot 0)$ & $9 \cdot 2(0 \cdot 7)$ & $<0 \cdot 001$ \\
$\mathrm{PaCO}_{2}(\mathrm{kPa})$ & $7 \cdot 2(1 \cdot 0)$ & $5 \cdot 7(0 \cdot 3)$ & $<0 \cdot 01$ \\
$\mathrm{H}^{+}(\mathrm{nmol} / \mathrm{l})$ & $41(2 \cdot 5)$ & $40(3 \cdot 4)$ & $\mathrm{NS}$ \\
$\mathrm{ANP}(\mathrm{pg} / \mathrm{ml})$ & $120(50)$ & $54(15)$ & $<0 \cdot 01$ \\
\hline
\end{tabular}

FEV 1 -forced expiratory volume in one second; FVCforced vital capacity; $\mathrm{PaO}_{2}, \mathrm{PaCO}_{2}$-partial pressures of oxygen and carbon dioxide; $\mathrm{H}^{+}-$hydrogen ion concentration; ANP-atrial natriuretic peptide.
Intracardiac pressures were measured by averaging over three respiratory cycles and were zero referenced to a point five $\mathrm{cm}$ below the sternal angle. Mean values were obtained by electrical integration. Cardiac output was determined by the thermodilution technique. The mean of at least three values which varied by less than $10 \%$ was used in the analysis. Heart rate was recorded continuously by an ECG monitor.

\section{Radionuclide technique}

Right ventricular ejection fraction (RVEF) was measured by gated radionuclide ventriculography following a peripheral venous injection of $750 \mathrm{MBq}$ technetium-99m labelled human serum albumin. ${ }^{4}$ The normal value of RVEF in our laboratory is $>0 \cdot 40.4^{42}$ Measurements were made at the end of the cardiac catheterisation when the patients breathed air.

\section{Magnetic resonance imaging (MRI)}

An MRI scan of the thorax was carried out 2-5 days after the right heart catheterisation in eight patients. A cardiac gating technique was used to acquire data at end systole and end diastole as previously described. ${ }^{23} 24$ Multiple images were obtained from the cardiac apex up to, but excluding, the right ventricular outflow tract in a plane orthogonal to the interventricular septum using $16 \mathrm{~mm}$ slice thickness. The right ventricular "free" wall volume (RVWV) and chamber volume were calculated by measuring the area from irregular regions of interest drawn around these structures in each image. Summation of the product of each area and the slice thickness was used to obtain the volume. Each image was analysed by an operator (LT) who was unaware of the clinical or haemodynamic data. Right ventricular end diastolic chamber volumes (RVEDV) could only be assessed in six of the eight patients. Details of the technique and its reproducibility have been published previously. ${ }^{23}$ As previously described, the right ventricular end diastolic volume excludes the outflow tract which improves the reproducibility of the measurement but underestimates the true absolute value of the ventricular volume. ${ }^{23}$

\section{PLASMA ANP}

Ten ml samples of blood were removed and placed into EDTA tubes to measure plasma levels of ANP. Plasma was rapidly separated, stored at $-70^{\circ} \mathrm{C}$, and measured in batches within two months by a specific radioimmunoassay..$^{25}$ ANP antibody was raised in the rabbit by conjugation of synthetic ANP 1-28 with bovine thyroglobulin using carbodiimide as the coupling agent. ${ }^{25}$ Iodine-125 labelled ANP was purchased from Amersham International Laboratories. ANP was extracted from plasma using Sep-PaK C-18 cartridges (Waters Associates, UK) and eluted with a mixture of ethanol, water, and acetic acid. The lower limit of detection for the assay was $10 \mathrm{pg} / \mathrm{ml}$. The level of ANP was measured by a specific and sensitive radio- 
immunoassay technique, using ${ }^{125} \mathrm{I}-\mathrm{ANP}$ (1-28). The normal mean (SD) plasma level of ANP in our laboratory in patients undergoing cardiac catheterisation is 45 (15) $\mathrm{pg} / \mathrm{ml}^{27}$

\section{STATISTICAL METHODS}

Comparison between mean values was made using the Wilcoxon rank test. Correlation coefficients were calculated from standard equations.

\section{PROTOCOLS}

\section{Haemodynamic study}

In the haemodynamic study ANP was measured in samples of blood from the right atrium, pulmonary artery, peripheral vein, and peripheral artery, both when the patients breathed room air and when hypoxaemia was corrected by breathing oxygen given at a flow rate of $2-31 / \mathrm{min}$ by nasal prongs for 30 minutes to achieve a $\mathrm{PaO}_{2} \geqslant 8 \cdot 0 \mathrm{kPa}$.

\section{Serial measurements of $A N P$ levels during acute exacerbations of COPD}

Patients presenting to our hospital with an acute exacerbation of COPD had samples of venous blood withdrawn on admission while breathing room air and again after breathing oxygen for one hour (2 $1 / \mathrm{min}$ via nasal prongs). On each of the subsequent two days ANP levels were again measured while the patient breathed oxygen. Each sample was taken in the morning. If diuretic therapy was prescribed this was administered after the blood sample for ANP measurement was withdrawn. Since all samples were taken in the morning, no diuretics were given for at least 12 hours before the withdrawal of the blood samples. None of the patients were given respiratory stimulants, catecholamine infusions nor haemodynamically active drugs other than $\beta_{2}$ agonists. Oxygen, diuretics, nebulised $\beta_{2}$ agonists, and antibiotics where appropriate were thus the only drugs which were administered. Sodium intake was not controlled although no salt was added to the normal ward diet. Blood was also sampled six weeks after the exacerbation at a time when the patients were clinically stable.

\section{ANP levels in relation to clinical patterns of COPD}

A further 20 samples of blood were taken for ANP measurement from patients with COPD who were clinically stable at least six weeks after their last exacerbation of COPD. These patients were categorised clinically depending on the presence or absence of hypercapnia and past history of peripheral oedema (see above).

\section{Results}

HAEMODYNAMIC STUDY

All 20 patients who underwent right heart catheterisation had severe airflow limitation, were hypoxaemic, and the majority also had hypercapnia (table 1). However, they had a wide range of mean pulmonary arterial pressures (mean 27; range $16-45 \mathrm{~mm} \mathrm{Hg}$ ). Plasma ANP levels were not significantly dif-
Table 3 Effect of oxygen (2 l/min, nasal prongs) on plasma ANP levels in peripheral or central blood in 20 patients with stable COPD. Values are mean (range)

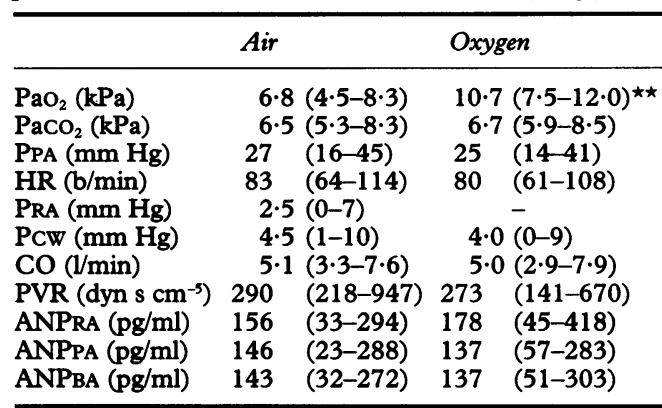

PRA - mean right atrial pressure; PPA-mean pulmonary arterial pressure; $\mathrm{HR}$-heart rate; $\mathrm{PCW}$-pulmonary capillary wedge pressure; $\mathrm{CO}$-cardiac output; PVRpulmonary vascular resistance; ANPRA-ANP in right atrium; ANPPA-ANP in pulmonary artery; ANPBAANP in brachial artery. ${ }^{\star \star} \mathrm{p}<0.01$

ferent when measured in the right atrium, pulmonary artery, or peripheral arterial blood (table 3). Oxygen given for 30 minutes (2-3 $1 /$ min via nasal prongs) did not change either the mean pulmonary arterial pressure nor the level of plasma ANP, but did correct the hypoxaemia $\left(\mathrm{PaO}_{2}>8.0 \mathrm{kPa}\right)$ in all but one patient (table 3). No significant correlation was found between the level of plasma ANP and any of the pulmonary haemodynamic variables or the blood gas values $(r=0 \cdot 1-0 \cdot 4$, p > 0.05). In eight patients who had an MRI scan within 3-5 days (RVWV 38 (11) $\mathrm{ml}$, RVEDV 40 (17) $\mathrm{ml}$ ), however, significant correlations were found between the right ventricular dimensions-that is, RVWV $(r=0.84, \mathrm{n}=8, \mathrm{p}<0.01$, fig 1$)$ and RVEDV $(r=0.81, \mathrm{n}=6, \mathrm{p}<0.05$, fig 2)-and the plasma ANP level measured in peripheral blood. The mean (SD) RVEF measured by radionuclide ventriculography in these patients $(n=10)$ was $0.36(0 \cdot 10)$. There was no significant correlation between RVEF and plasma ANP level $(r=-0.45, \mathrm{p}>0.05)$.

SERIAL MEASUREMENTS OF ANP IN PATIENTS WITH ACUTE EXACERBATIONS OF COPD

Twenty patients presenting with an acute exacerbation of COPD who required hospital admission were divided into two groups: 10 who presented on admission with peripheral

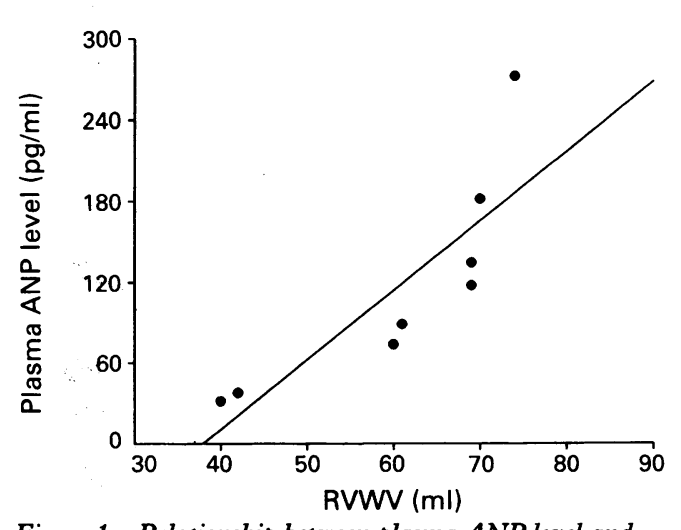

Figure 1 Relationship between plasma ANP level and right ventricular wall volume (RVWV) in eight patients with chronic obstructive pulmonary disease $(r=0 \cdot 84$, $p<0.01$ ). ,


Figure 2 Relationship between plasma ANP level and right ventricular end diastolic volume (RVEDV) in six patients with chronic obstructive pulmonary disease $(r=0.81$ $p<0.05)$.

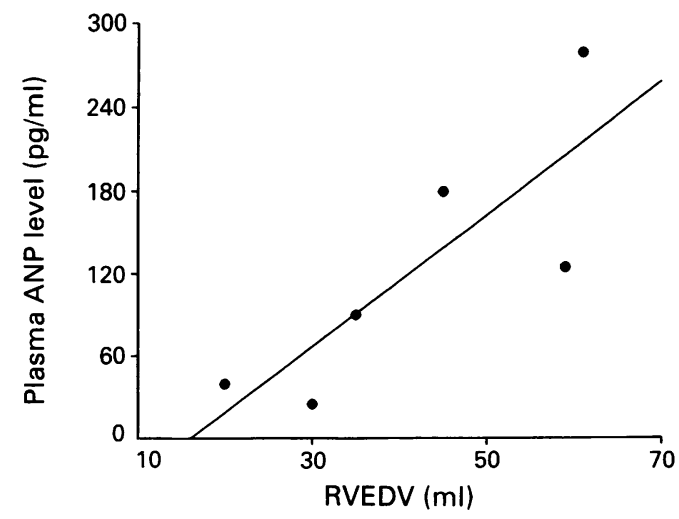

oedema and 10 who presented without. There was no difference in the level of $\mathrm{PaO}_{2}$ on admission (measured when breathing air) in those with oedema $(5.6(1.2) \mathrm{kPa})$ and those without $(6 \cdot 1(0.5) \mathrm{kPa})$. However, those with oedema were more hypercapnic $\left(\mathrm{PaCO}_{2} 7 \cdot 2(1 \cdot 3) \mathrm{kPa}\right)$ and acidotic $\left(\mathrm{H}^{+}\right.$ion 47(5) nmol/l) than those without oedema $\left(\mathrm{PaCO}_{2} 6 \cdot 1(2 \cdot 3) \mathrm{kPa} ; \mathrm{H}^{+}\right.$ion 44 (3) $\mathrm{nmol} / \mathrm{l}$; $\mathrm{p}<0.05)$. The $\mathrm{FEV}_{1}$ measured at the time of discharge was also similar in both groups (patients with oedema, $0.57(0.17) 1$; patients without oedema, $0.69(0.30) 1 ; \mathrm{p}>0.05)$. Patients without oedema had a statistically lower level of plasma ANP on admission both when breathing air and oxygen $(21 / \mathrm{min}$ for one hour) (87(43) $\mathrm{pg} / \mathrm{ml}$ on air; $96(21) \mathrm{pg} / \mathrm{ml}$ on oxygen) compared with those presenting with oedema $(302(185) \mathrm{pg} / \mathrm{ml}$ on air; 281 (199) $\mathrm{pg} / \mathrm{ml}$ on oxygen; $\mathrm{p}<0.01)$ ). Oxygen (2 $1 / \mathrm{min}$ for one hour) increased the $\mathrm{PaO}_{2}$ in patients with and without oedema to $7 \cdot 6$ $(1.8) \mathrm{kPa}$ and $8.5(1.7) \mathrm{kPa}$ respectively $(\mathrm{p}<$ $0.05)$, and the $\mathrm{PaCO}_{2}$ to $7.5(1.9) \mathrm{kPa}$ and $6.4(1.2) \mathrm{kPa}(\mathrm{p}<0.05)$, but did not change the level of plasma ANP for the group as a whole (ANP on air 205 (96) pg/ml; ANP on oxygen $194(103) \mathrm{pg} / \mathrm{ml}, \mathrm{p}>0.05)$ nor when those with or without oedema were analysed separately.

Plasma ANP levels during the second and third day after admission did not change significantly in the group as a whole nor when the values in those with and without oedema were analysed separately (fig 3). There was, however, a significant fall in ANP while breathing oxygen on day $2(168(132) \mathrm{pg} / \mathrm{ml})$ and day 3 (158 (11) $\mathrm{pg} / \mathrm{ml}$ ) compared with the values on admission $(256(181) \mathrm{pg} / \mathrm{ml}$, $\mathrm{p}<0.05)$ for the whole group. The mean plasma ANP level was still significantly higher on day 3 in those with oedema (232 (46) $\mathrm{pg} / \mathrm{ml}$ ) than in those without oedema (88 (17) $\mathrm{pg} / \mathrm{ml}, \mathrm{p}<0.05)$. Six weeks after the acute exacerbation, when the patients were clinically stable, the level of ANP in the plasma was unchanged in those who presented without oedema (87 (16) $\mathrm{pg} / \mathrm{ml}$ ) compared with the level on admission (87 (43) $\mathrm{pg} / \mathrm{ml}$, $p>0.05$ ) but had fallen further in those who presented with oedema (118 (47) $\mathrm{pg} / \mathrm{ml}$; $\mathrm{p}<0.05$ ) (fig 3 ). In the patients who had peripheral oedema at the time of admission the fall in body weight correlated with the fall in the level of plasma ANP $(r=0.85$; $p=0.002$ ) (fig 4).

\section{ANP IN THE DIFFERENT CLINICAL PATTERNS}

OF COPD

Patients who were defined as having the "blue and bloated" syndrome of COPD had a lower $\mathrm{FEV}_{1}$, were more hypoxaemic, and were hypercapnic compared with those considered to be "pink puffers" (table 2).

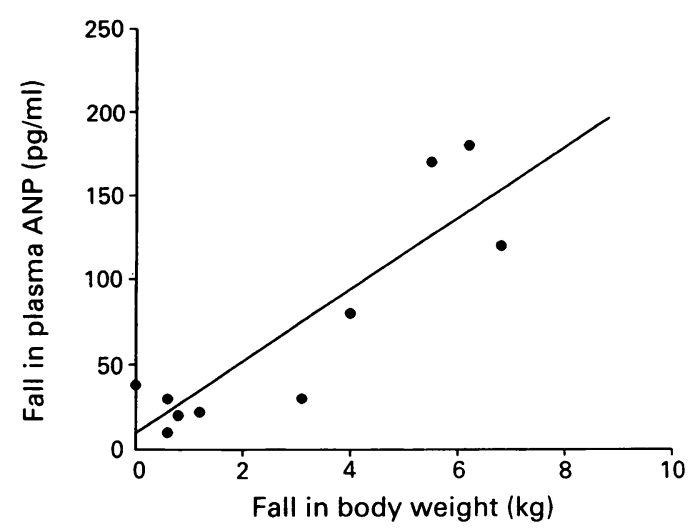

Figure 4 Correlation between the changes in plasma ANP level and body weight over the first three days during exacerbations of chronic obstructive pulmonary disease in 10 patients $(r=0.85, p=0.002)$.

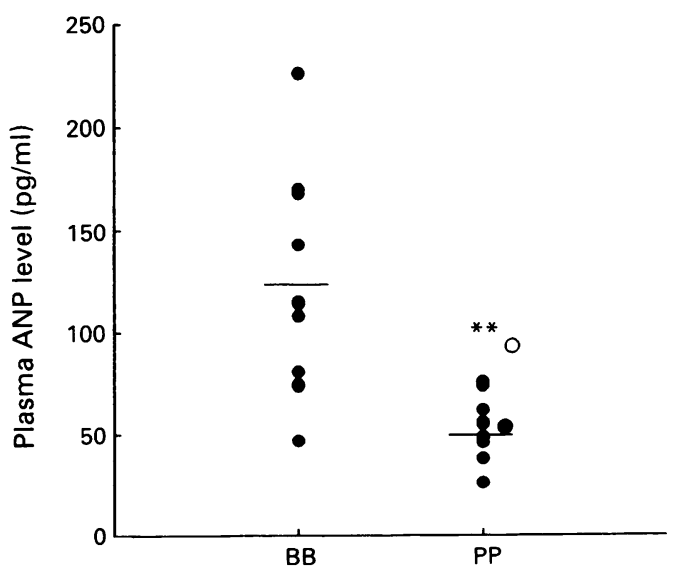

Figure 5 Plasma ANP level in patients with the "blue and bloated" (BB) $(n=11)$ or "pink and puffing" (PP) $(n=9)$ patterns of chronic obstructive pulmonary disease. Individual and mean values are shown. The mean value for $B B$ is significantly greater than that for $P P\left(\star_{p}<0.01\right)$.
Figure 3 Serial measurements of plasma ANP levels in patients with (hatched bars) and without (closed bars) oedema during an exacerbation of chronic obstructive pulmonary disease on day 1, when breathing air or oxygen (2-3 l/min for one hour), and on days 2 and 3 , and 6 weeks later when clinically stable when breathing oxygen. ${ }^{* *_{p}}<0.01$, $\star_{p}<0.05$ comparing patients with and without oedema; $\dagger_{p}<0.05$ comparing measurements on day 1 and at six weeks. 
The level of plasma ANP measured in those with the "blue and bloated" type of COPD was higher than in those with the "pink and puffing" type (table 2) although there was clearly some overlap between the groups (fig 5).

\section{Discussion}

ANP is an important humoral regulator of salt and water balance and of arterial pressure. ${ }^{14}$ When given to healthy subjects it causes natriuresis, vasodilation, and can also suppress the activity of the renin-angiotensinaldosterone system, ${ }^{1819}$ actions which would be beneficial in cor pulmonale.

Plasma ANP levels are elevated in patients with primary or secondary pulmonary hypertension 16212829 and correlate with both the mean pulmonary arterial (PPA) and right atrial pressures in some studies ${ }^{172}$ but not in others. $^{21}$ These conflicting data may arise because of the small number of patients studied and the narrow range of haemodynamic variables. Plasma ANP levels rise in response to the increase in PPA during exercise, ${ }^{28}$ presumably because of an increase in right atrial pressure and atrial distension. However, in a group of patients with primary pulmonary hypertension with raised PPA levels (mean PPA 74(13) $\mathrm{mm} \mathrm{Hg}$ ) plasma ANP levels were elevated in all but one patient despite normal right atrial pressures. ${ }^{29}$

Our study helps to resolve these conflicting data in a larger group of patients with a wide range of pulmonary arterial pressures. In this group we found no significant correlation between pulmonary arterial or right atrial pressure and simultaneously sampled plasma ANP levels. Furthermore, the levels of plasma ANP in patients with hypoxic COPD were similar in central venous and peripheral arterial blood, whereas others have found higher levels of ANP in central than in peripheral blood. ${ }^{17}$ Since atrial stretch is thought to be the major stimulus to the release of ANP it is not surprising that central venous pressure measurements, which are a poor reflection of atrial stretch, do not correlate well with the levels of ANP. Surprisingly, in previous studies the correlation between plasma ANP levels and right atrial pressure was present even when the atrial pressure remained within the normal range, ${ }^{17}$ although this relationship was not confirmed in other studies. $^{21}$

Although we were not able to make direct measurements of atrial chamber size, we found a significant relationship between right ventricular end diastolic chamber volume and right ventricular wall volume, measured by MRI, and plasma ANP levels. We presume that an increase in right ventricular volume would also be associated with an increased atrial volume and presumably atrial stretch. ${ }^{30}$ The correlation between ANP levels and right ventricular wall volume is interesting since in animal studies hypoxia is associated with both increased right ventricular mass and, in addition, an increase in messenger RNA expression for ANP in the right ventricular wall. ${ }^{31}$

These data confirm the presence of elevated levels of plasma ANP in 60 patients with COPD. Although plasma ANP levels were higher in patients with an exacerbation of COPD than in normal subjects, very high levels $(>120 \mathrm{pg} / \mathrm{ml}$ ) occurred only in those with oedema. This finding did not relate to the severity of the disease. Previous studies suggest that, during an exacerbation of COPD, pulmonary arterial pressure rises $^{32}$ which presumably would cause release of ANP as a result of increased atrial stretch.

An increase in central blood volume secondary to activation of the renin-angiotensinaldosterone system and consequent salt and water retention ${ }^{33}$ could also increase atrial stretch and ANP release. High levels of ANP should have a protective role in the development of oedema in patients with COPD and hypoxia due to its beneficial haemodynamic effects and the inhibitory effects of ANP on the renin-angiotensin system. ${ }^{34}$ Furthermore, the release of ANP remains responsive to physiological manipulations in patients with COPD. ${ }^{35}$ However, why sodium and water retention still occurs in patients with hypoxic COPD and oedema in the face of very high levels of plasma ANP remains unclear. Several explanations are possible such as a blunted renal response to $\mathrm{ANP}^{36}$ or the possibility that the suppressive effect of ANP on the renin-angiotensin axis is outweighed by the stimulatory effect of inadequate renal perfusion $^{37}$ on the renin-angiotensin system. ${ }^{38}$

Since the level of hypoxaemia was not different in patients with exacerbations of COPD with and without oedema, both groups would presumably have pulmonary hypertension at least acutely. ${ }^{32}$ However, the degree of hypercapnia and acidosis was higher in those with oedema, as noted in a previous study, ${ }^{39}$ and may have contributed to a further increase in pulmonary arterial pressure, stimulation of the renin-angiotensin system, reduction of effective renal plasma flow, and thus the filtered sodium load. ${ }^{40}$ The fall in plasma ANP levels with treatment in patients with oedema is likely to be due to a combination of factors including the improvement in blood gas values, a fall in pulmonary arterial hypertension, ${ }^{32}$ and reduction in central venous pressure consequent on a diuresis Support for this latter mechanism comes from the relationship between the fall in body weight and the fall in ANP levels in these patients.

The pathogenesis of the oedema in cor pulmonale remains unknown. ${ }^{6}$ The adaptive mechanisms which occur in response to chronic pulmonary hypertension, such as an increase in right ventricular end diastolic volume, ${ }^{1}$ may also produce a chronic elevation of ANP levels. This hypothesis is supported by the presence of elevated ANP levels in those patients who had hypercapnia and a past history of peripheral oedema compared with those who were normocapnic and had never had oedema. An increased level of ANP consequent upon the higher levels of pulmonary arterial pressure in the "blue bloaters" may be one of the reasons why oedema does not always develop in patients with COPD and 
pulmonary hypertension, even during exacerbations. ${ }^{532}$

Our data show that oxygen given acutely to hypoxic patients, whether in a stable state or during an exacerbation, has no effect on ANP levels. These findings confirm those of other workers in studies of patients with stable COPD. ${ }^{21}$ Furthermore, short term discontinuation of oxygen does not appear to affect the levels of ANP in patients with hypoxic COPD treated with long term oxygen therapy. ${ }^{27}$ The effect of long term oxygen therapy on plasma ANP levels has not been studied, although oxygen given over six days to hypoxic patients with COPD did not alter the level of ANP in the plasma. ${ }^{28}$

The results of this study suggest that the complex interactions between pulmonary haemodynamics, blood gas values, the reninangiotensin system, and ANP in patients with exacerbations of COPD with and without oedema are worthy of further study, since they may lead to more logical treatment of patients with exacerbations of COPD and oedema.

Dr K Skwarski was funded by the British Heart Foundation. This study was also supported by the Norman Salvesen Emphysema Research Fund.

Thanks are accorded to Mrs C. Hendrie and Mrs E Nea for typing the manuscript, and to Miss A Barratt for technical assistance.

1 Fishman AP. State of art: chronic cor pulmonale. Am Rev Respir Dis 1976;114:775-94.

2 McFadden ER, Braunwald E. Cor pulmonale and pulmonary thromboembolism. In: Braunwald E, ed. Heart disease, a text book of cardiovascular medicine. Philadelphia: Saunders, 1988:1597-617.

3 Wilkinson M, Langhorne CA, Heath D, Barer GR Howard P. A pathophysiological of 10 cases of hypoxi cor pulmonale. $Q \mathcal{F} \mathrm{Med}$ 1988;66:65-87.

4 MacNee W, Xue QF, Hannan WJ, Flenley DC, Adie CJ, Muir AL. Assessment by radionuclide angiography of right and left ventricular function in chronic bronchitis and emphysema. Thorax 1983;38:494-500.

5 MacNee W, Wathen CG, Flenley DC, Muir AL. Righ ventricular function in patients with stable and decompensated pulmonary heart disease: the effects of controlled oxygen therapy. Am Rev Respir Dis 1988;137: 1289-95.

6 Richens JM, Howard P. Oedema in cor pulmonale. Clin Sci 1982;62:255-9.

7 Campbell RHA, Brand HL, Cox JR, Howard P. Body weight and body water in chronic cor pulmonale. Clin Sci 1975;49:323-35.

8 Farber MO, Weinberger MH, Robertson GL, Fineberg NS. The effects of angiotensin-converting enzyme inhibition on sodium handling in patients with advanced chronic obstructive pulmonary disease. Am Rev Respir Dis 1987;134:820-6.

9 Reihman DM, Farber MO, Weinberger MH, Henry DP, Fineberg NS, Dowdeswell IR, et al. Effects of hypoxaemia on sodium and water excretion in chronic obstructive lung disease. Am $\mathcal{F}$ Med 1985;78:87-94.

10 Mannix ET, Dowdeswell I, Carlone S, Palange P, Arouoff GR, Farber MO. The effects of oxygen on sodium excretion in hypoxaemic patients with chronic obstructive lung disease. Chest 1990;27:840-4.

11 de Bold AJ, Borenstein HB, Veress AT, Sonnenberg H. A rapid and potent natriuretic response to intravenous injection of atrial myocardial extract in rats. Life Sci 1981;28:89-94.

12 Raine AEG, Erne $P$, Burgisser E, Muller F, Bolli $P$ Burkart F, et al. Atrial natriuretic peptide and atrial pressure in patients with congestive heart failure. $N$ Engl pressure in patients with

13 Yamaji $T$, Ishibashi $M$, Takaku F. Atrial natriuretic factor in human blood. $\mathcal{F}$ Clin Invest 1985;76:1705-9.

14 Espiner EA, Richards AM. Atrial natriuretic peptide. An important factor in sodium and blood pressure regulation. Lancet 1989;i:707-10.

15 Hartler E, Weissel M, Stummvoll HK, Woloszczuk W, Punzengruber $\mathrm{CH}$, Ludvik B. Atrial natriuretic peptide concentrations in blood from right atrium in patients with severe right-heart failure. Lancet 1985;ii:93-4.

16 Lang RE, Tolken H, Ganten D, Luft FC, Ruskoaho H, Unger T. Atrial natriuretic factor-a circulating hormone stimulating by volume loading. Nature $1985 ; 314$
$264-6$

17 Burghuber OC, Harrter E, Punzengruber Ch, Weissel M, Woloszczuk W. Human atrial natriuretic peptide secretion in precapillary pulmonary hypertension. Clinical study in patients with COPD and interstitial fibrosis. Chest 1988;92:31-7.

18 Richards AM, Tonolo G, Polonia J, Montorsi P. Contrasting plasma atrial natriuretic factor concentrations during comparable natriuresis with infusions of atrial natriuretic factor and saline in normal man. Clin Sci 1988;75:455-62.

19 Richards AM, Ikram H, Yandle TG, Nicholls MG, Webster MW, Espiner EA. Renal, haemodynamic, and hormonal effects of human alpha atrial natriuretic peptide in healthy volunteers. Lancet $1985 ; \mathrm{i}: 545-8$.

20 Adnot S, Charbrier PE, Andrivet P, Viossat I, Piquet J, Brun-Buisson $\mathrm{C}$, et al. Atrial natriuretic peptide concentrations and pulmonary haemodynamics in patients with pulmonary artery hypertension. Am Rev Respir Dis 1987;136:951-6.

21 Winter RJD, Davidson AC, Treacher D, Rudd RM, Anderson JV, Meleanger L, et al. Atrial natriuretic peptide concentrations in hypoxic secondary pulmonary hypertension: relation to haemodynamic and blood gas variables and response to supplemental oxygen. Thorax 1989;44:58-62.

22 Xue QF, MacNee W, Flenley DC, Hannan WJ, Adie CJ, Muir AL. Can right ventricular performance be assessed by gated equilibrium ventriculography. Thorax 1983;38: 486-93.

23 Smith MA, Ridgway JP, Brydon JWE, Been M, Douglas $\mathrm{RM}$, Kean DM, et al. ECG-gated T1 images of the heart. Phys Med Biol 1986;3:771-8.

24 Turnbull LW, Ridgway JF, Biernacki W, McRitchie $\mathrm{H}$, Muir AL, Best JJK, et al. Measurement of right ventricular dimensions in chronic obstructive pulmonary disease using magnetic resonance imaging. Thorax 1990; 45:597-601

25 Harter E, Woloszczuk W, Stummvoll HK. Radioimmunoassay of atrial natriuretic peptides in human plasma. Clin Chem 1986;32/33:441-5.

26 Freestone S, MacDonald TM, Jeffrey RF, Brown JE, Lee MR. The renal effects of atrial natriuretic peptide in man are not attenuated by $(+)$ sulpiride. $B r \mathcal{F}$ Pharmacol 1989;27:13-8.

27 Brown JE, Lee MR, Boon NA. Effect of cardiac tamponade on atrial natriuretic peptide concentrations: influence of stretch and pressure. Clin Sci 1990;79:377-80.

28 Watanabe H, Furui H, Yamaki K, Suzuki K, Takagi K, Sasamoto $\mathrm{M}$, et al. Plasma atrial natriuretic polypeptide in chronic respiratory disease. Am Rev Respir Di 1987;135 (Suppl):A145.

29 Morice A, Pepke-Zaba J, Davies L, Brown M Higgenbottam T. Plasma levels of atrial natriuretic peptide in primary pulmonary hypertension. Thorax 1987;42:720.

30 Au J, Brown JE, Lee MR, Boon NA. Effect of cardiac tamponade on atrial natriuretic peptide concentrations: influence of stretch and pressure. Clin Sci 1990;79:377-80.

31 Raffestin B, Adnot S, Mercadier JJ, Levame M, Duc P, Braquet $\mathrm{P}$, et al. Synthesis and secretion of atrial natriuretic factor during chronic hypoxia: a study in the conscious instrumented rat. Clin Sci 1990;78:597-603.

32 Abrahams AS, Cole RV, Green ID, Headworth-Whitty RB, Clerk SW, Bishop JM. Factors contributing to the reversible pulmonary hypertension in patients with acute respiratory failure studied by serial observations during recovery. Circ Res 1969;26:51-60.

33 Colice GL, Farber M, Rose CE, Raff H, Ramirez G. Fluid balance in acute and chronic lung disease. $\mathrm{Am}$ Rev Respir Dis 1988;134:1052-3.

34 Adnot $S$, Andrivet $P$, Chabrier PE, Piquet J, Plas $P$, Blaquet $\mathrm{P}$, et al. Atrial natriuretic factor in chronic obstructive lung disease with pulmonary hypertension Physiological correlates and response to peptide infusion. $\mathcal{F}$ Clin Invest 1989;83:986-93.

35 Carlone S, Palange P, Mannix ET, Farber MO, Aronoff $\mathrm{GR}$, Brier $\mathrm{M}$, et al. Atrial natriuretic peptide renin aldosterone in obstructive lung disease and heart failure. Am ₹ Med Sci 1989;298:243-8.

36 Laragh JH, Cody RJ, Covit AB, Atlas SA. The renin system and atrial natriuretic hormone in congestive heart failure. Acta Med Scand 1986;707:45-53.

37 Farber MO, Weinberger MH, Robertson GL, Fineberg NS, Manfred IF. Abnormalities of sodium and $\mathrm{H}_{2} \mathrm{O}$ handling in chronic obstructive lung disease. Arch Intern Med 1982;142:1326-30.

38 Shenker Y, Sider RS, Ostafin EA, Grekin RJ. Plasma levels of immunoreactive atrial natriuretic factor in healthy subjects and patients with oedema. $\mathcal{F}$ Clin Invest 1985;76:1684-7.

39 Farber MO, Bright TP, Strawbridge RA, Robertson GL Manfredi F. Impaired water handling in chronic obstructive lung disease. $\mathcal{F}$ Lab Clin Med 1975;85:41-9.

40 Weitzenblum F, Santegean A, Ehrhart M, Memmosser $M$, Hirth $\mathrm{CH}$, Roegel E. Long-term course of pulmonary arterial pressure in chronic obstructive pulmonary disease. Am Rev Respir Dis 1984;130:993-8. 